\title{
DESIGN ULTIMATE STRENGTH OF R/C INTERIOR BEAM-COLUMN JOINTS WITH FLOOR LEVEL DIFFERENCE USING MECHANICAL ANCHORAGES
}

益尾 潔— $* 1$

キーワード :

機械式定着, 鉛直段差, 十字形接合部, 設計終局耐力, 接合部有効せい, 梁主筋定着長さ

Keywords:

Mechanical anchorage, Floor level difference, Interior beam-column joint, Design ultimate strength, Effective depth of joint, Development length of beam reinforcement
Kiyoshi MASUO

Recently, ultimate strength of $\mathrm{r} / \mathrm{c}$ interior beam-column joints with floor level difference using mechanical anchorages has been researched. However, design method of such joints is not necessarily clear. This paper shows its design criteria and mechanism based on past tests result. Consequently, estimation method of design ultimate strength of such joints is clarified.

\section{1.はじめに}

鉄筋コンクリート建物では，建築計画上しばしば設けられる鉛直 段差を有する鉛直段差梁付き十字形接合部は, 図 1 の Type A と Type B に大別される。TypeA は左右梁の上下面が一致しない場合, TypeB は左右梁の上面または下面が一致する場合である。

機械式定着工法による鉛直段差梁付き十字形接合部については, 文献 1)〜7)の実験研究が行われている。しかし，これらの柱梁接合 部の設計方法は必ずしも明確でない ${ }^{8)}$ 。本論文では, 文献 1) 7)の 実験結果を踏まえ, 機械式定着工法による鉛直段差梁付き十字形接 合部の設計終局耐力の算定方法を明らかにする。

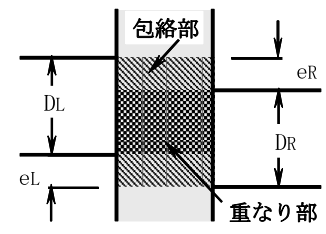

(a) Type A

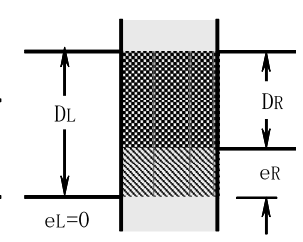

(b) Type B
図 1 段差梁付き十字形接合部の基本タイプ

\section{2. 鉛直段差梁付き十字形接合部の基本事項}

\section{1 設計条件}

梁主筋が定着破壊しなければ，図 2 のように，Type A の場合， 左右梁重なり部の入力せん断力 $V_{h} 2$ は仕口面側入力せん断力 $V_{h}$ より も大きく，段差なし接合部の入力せん断力と同じになる。Type B の 場合も, 左右梁重なり部の入力せん断力 $\mathrm{Vh} 2$ は段差なし接合部の入 力せん断力と同じになる。したがって, Type A, Type B の終局強度 設計用せん断力 $V_{\text {muh }}$ は，段差なし十字形接合部と同様，梁曲げ終局 耐力時柱せん断力 cQgu を用いると，式(1)で算定できる ${ }^{8)}$ 。

$$
\begin{aligned}
& V_{\text {muh }}=\xi_{\mathrm{h}} \cdot{ }_{\mathrm{c} Q g u} \\
& \quad \mathrm{cQgu}=\left\{\left(\mathrm{Mguo}_{\mathrm{gu}}+\mathrm{Mguo}^{\prime}\right) / \ell_{\mathrm{o}}\right\} \cdot(\ell / \mathrm{h}) \\
& \xi_{\mathrm{h}}=(\mathrm{h} / \ell) \cdot\left(\ell_{0} / \mathrm{jtg}\right)-1
\end{aligned}
$$

ここに、 $\ell$ : スパン長 (柱心間距離), $\ell_{0}$ : 梁内法スパン長, $\mathrm{h}:$ 階高 $j \mathrm{tg}=\left(j \mathrm{tg} 1+j_{\mathrm{tg} 2}\right) / 2, \quad j \mathrm{tg} 1, j \mathrm{tg} 2:$ 左右梁上下主筋の重心間距離 Mguo, Mguo' : 左右梁の曲げ終局耐力 ${ }^{8)}$

両梁材端部仕口面での梁曲げ終局耐力 Mguo と Mguo'が同じ場合, 式 (1)による十字形接合部の終局強度設計用せん断力 $V_{\text {muh }}$ は, ト形接 合部の終局強度設計用せん断力の 2.0 倍になる。ここで, 卜形接合 部の場合も，梁主筋は定着破壊しないとする。

(注) (a) 図では, $\mathrm{Tg}=\mathrm{Tg}, \mathrm{Cg}_{\mathrm{g}}=\mathrm{Cg}$ 'を仮定し， $\mathrm{Vh} 2=\mathrm{Vh} 1+\mathrm{Cg}=\mathrm{Vh} 1+\mathrm{Cg}$ 'としている。

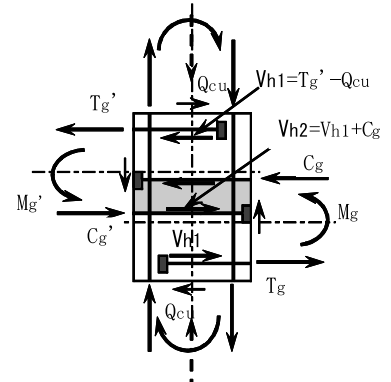

(a) Type A

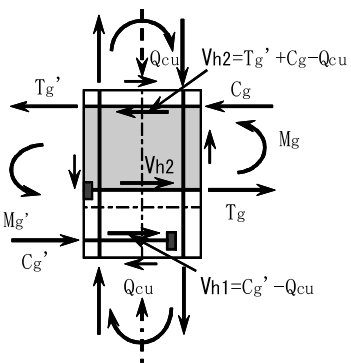

(b) Type B
図 2 段差梁付き十字形接合部の入力せん断力

ト形および十字形接合部のせん断終局耐力 $V_{p u h}$ は, 式(4)で算定 できる ${ }^{9)}$ 。同式中の $\phi \cdot F_{j} \cdot b_{j}$ が同じ場合, 梁主筋定着長さ $\ell_{a g}$ を $(3 / 4) D_{c}$ とすると，卜形接合部に対する十字形接合部のせん断終局 耐力の比は $1 /(0.7 \times 3 / 4)=1.90$ となる。Dcは柱せいを示す。

$\mathrm{V}_{\text {puh }}=\kappa \mathrm{u} \cdot \phi \cdot \mathrm{F}_{\mathrm{j}} \cdot \mathrm{b}_{\mathrm{j}} \cdot \mathrm{D}_{\mathrm{jh}}$

ここに、 $\kappa u$ ： 柱梁接合部の形状係数

（卜形接合部： $\kappa \mathrm{u}=0.7$, 十字形接合部 : $\kappa \mathrm{u}=1.0$ )

$\phi ：$ 直交梁の有無による補正係数

$F_{j}$ : コンクリート基準せん断強度

$b_{j}$ ：接合部有効幅、 $D_{j h}$ ：接合部有効せい

卜形接合部 : $\mathrm{D} j \mathrm{~h}=\ell \mathrm{ag}$ ，段差なし十字形接合部 : $\mathrm{D}_{\mathrm{jh}}=\mathrm{Dc}_{\mathrm{c}}$

ト形および十字形接合部の設計条件は式 (5) となるので, ト形接合 部に対する十字形接合部の同式中の接合部耐力余裕度 $\lambda_{\mathrm{p}}$ の比は 
1.90/2. 0=0.95 となる。すなわち, 段差梁付き十字形接合部の場合, ト形接合部と見なすよりも段差なし十字形接合部と見なして設計す る方が安全側となる。

$$
V_{\text {puh }}>\lambda_{\mathrm{p}} \cdot V_{\text {muh }}
$$

\section{2 抵抗機構}

機械式定着工法による鉛直段差梁付き十字形接合部の場合, 図 3 に示すように, 重なり部梁主筋の定着形式には, 重なり部梁主筋を 反対側の最外縁柱主筋の外側で定着する貫通定着および柱梁接合部 内に定着する非貫通定着がある。

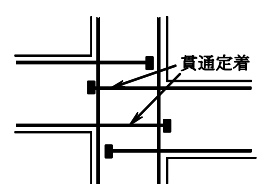

(a) 貫通定着

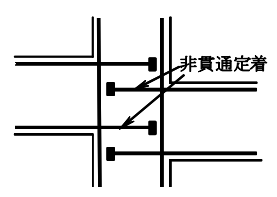

（b）非貫通定着
図 3 梁主筋の定着形式

文献 1)の実験によると, 重なり部梁主筋を貫通定着とした Type A の段差梁付き十字形接合部では, 図 4 に示寸ように, 正負加力時と もに, 左右梁の引張側梁主筋定着部から材端部圧縮域に向かうスト ラット $\mathrm{C}_{1}$ と接合部中央のストラット $\mathrm{C}_{2}$ の効果を期待できる。これ らより， $\mathrm{D}_{\mathrm{jh}}=\mathrm{D}_{\mathrm{c}}$ として接合部せん断終局耐力を算定してもよいと考 えられる。

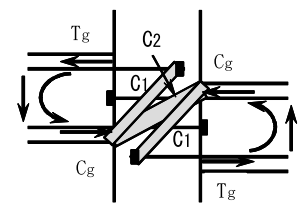

(a) 正加力時

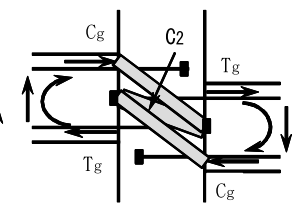

(b) 負加力時
図 4 Type A(貫通定着)段差梁付きの抵抗機構

重なり部梁主筋を貫通定着とした Type B の段差梁付き十字形接合 部では, 図 5 に示すように, ストラット $\mathrm{C}_{1}, \mathrm{C}_{2}$ が形成されるので, $\mathrm{D}_{j h}=\mathrm{D}_{\mathrm{c}}$ として接合部せん断終局耐力を算定してもよいと考えられる。 図 4, 図 5 は, 梁主筋定着金物から派生するストラットに着目した 図であり, 実際には, 上下柱の圧縮域間を結ぶストラットも生じる。

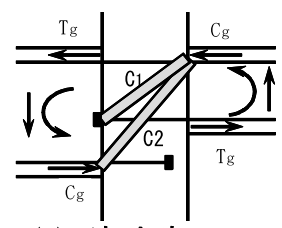

(a) 正加力時

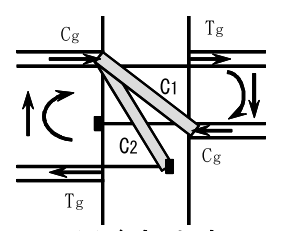

(b) 負加力時
図 5 Type B(貫通定着)段差梁付きの抵抗機構

文献 5)の実験によると, 重なり部梁主筋を非貫通定着とした Type A の段差梁付き十字形接合部の場合, 図 6 に示すように, 左梁 下端筋および右梁上端筋が引張側となる負加力時の最大耐力は、同 梁主筋が圧縮側となる正加力時よりも低く, 同梁主筋定着部近傍の 接合部コンクリートのひび割れ幅が拡大する傾向がある。すなわち,

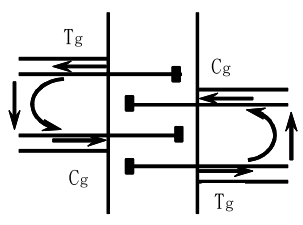

(a) 正加力時

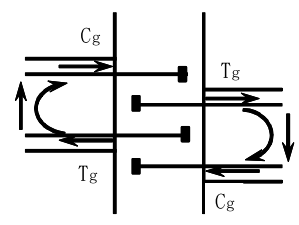

(b) 負加力時
図 6 Type A (非貫通定着) 段差梁付きの抵抗機構
非貫通定着の場合, 接合部せん断終局耐力は, $\mathrm{D} j \mathrm{~h}=\mathrm{D}$ c とせず、ト形 接合部と同様, $\mathrm{D}_{\mathrm{jh}}=\ell \mathrm{ag}$ として算定した方がよいと考えられる。

\section{3. 検討対象試験体}

本章では, 4 章および 5 章で検討する文献 1)～7）の機械式定着工 法による鉛直段差梁付き十字形接合部試験体の概要について述べる。 検討対象試験体の主な諸元を表 1 に示す。

文献 1) 5) の実験は Type A, 文献 6), 7) の実験は Type B の段差 梁付き十字形接合部試験体 (18 体)について行われている。Type A 試験体の左右梁の断面寸法および配筋はそれぞれ同じである。表 1 中の重なり率および定着筋率は, 下式で定義される(図 1 参照)。

重なり率 $=\mathrm{W} / \max (\mathrm{DL}, \mathrm{DR})$

$\mathrm{W}=\left\{\mathrm{DL}_{\mathrm{L}}+\mathrm{DR}^{-}(\mathrm{eL}+\mathrm{eR})\right\} / 2:$ 左右梁の重なり寸法

DL, DR : 左右梁せい, eL, eR : 左右梁の鉛直段差寸法

定着筋率 $=(\mathrm{na} 1+\mathrm{na} 2) /(\mathrm{n} 1+\mathrm{n} 2)$

na1, na2 : 梁 1 段筋と 2 段筋の定着筋本数

$\mathrm{n} 1, \mathrm{n} 2:$ 梁 1 段筋と 2 段筋の全引張鉄筋本数

以下に, 各実験計画の概要を示す。

1）文献 1)の段差付き試験体は Type A で, 重なり部梁主筋は貫通 定着とし, 段差なし試験体との違い, 両側直交梁付きと直交梁 なしとの違い, 梁主筋の鋼種 (SD490 とUSD685)の違いを調べて いる(図 7)。ただし，段差なし試験体はスラブ付きとしている。

2）文献 2)の試験体は Type A の片側直交梁付きで, 重なり部梁主 筋は非貫通定着とし，上端筋と下端筋の本数を変えている。

3）文献 3)の試験体は Type A で, 重なり部梁主筋は非貫通定着と し, 梁主筋の鋼種 (SD490 とUSD685) の違いを調べている。

4）文献 4)の試験体では, 圧縮強度 $\sigma \mathrm{B}$ が $95 \mathrm{~N} / \mathrm{mm}^{2}$ 程度の高強度コン クリートを用いた場合について, Type A の段差付き試験体と段 差なし試験体との違いを調べている。

5）文献 5)の試験体は Type A で, 重なり部梁主筋は非貫通定着と し，重なり率(75\%, 50\%,0) の違いを調べている(図 8)。

6）文献 6)の試験体は Type B で, 重なり率を $67 \%$ と，せいの大き い方の梁主筋本数およびコンクリート圧縮強度 $\sigma \mathrm{B}$ の違いを調 べている(図 9)。

7）文献 7)の試験体は Type B で, 左右梁せいを変え, 重なり率 表 1 検討対象実験の概要

\begin{tabular}{|c|c|c|c|c|c|c|c|c|c|c|c|c|c|}
\hline \multirow{2}{*}{$\begin{array}{l}\text { 段差 } \\
\text { Type }\end{array}$} & \multirow{2}{*}{$\begin{array}{c}\text { 試験 } \\
\text { 体 }\end{array}$} & \multirow{2}{*}{$\underset{\left(\mathrm{N} / \mathrm{mm}^{2}\right)}{\sigma \mathrm{B}}$} & \multicolumn{4}{|c|}{ 梁、柱断面寸法 (mm) } & \multicolumn{3}{|c|}{ 梁主筋 } & \multirow{2}{*}{$\begin{array}{l}\text { 重なり } \\
\text { 率 }\end{array}$} & \multirow{2}{*}{\begin{tabular}{|l} 
定着 \\
能率
\end{tabular}} & \multirow{2}{*}{$\begin{array}{l}\text { 定着 } \\
\text { 形式 }\end{array}$} & \multirow{2}{*}{ 齐 } \\
\hline & & & Bg & Dg & $\mathrm{Bc}$ & Dc & 配筋 & 鋼種 & $\ell_{\mathrm{ag}} / \mathrm{Dc}_{\mathrm{c}}$ & & & & \\
\hline $\begin{array}{ll}\text { 無 } \\
\end{array}$ & \begin{tabular}{|l|} 
No. 1 \\
\end{tabular} & \multirow{2}{*}{68.5} & \multirow{4}{*}{300} & \multirow{4}{*}{450} & \multirow{4}{*}{450} & \multirow{4}{*}{450} & \multirow{4}{*}{ 8-D19 } & \multirow{3}{*}{ SD 490} & - & $100 \%$ & 0 & A & \multirow{4}{*}{ 1) } \\
\hline \multirow{3}{*}{ TypeA } & \begin{tabular}{|l|} 
No. 2 \\
\end{tabular} & & & & & & & & \multirow{3}{*}{0.8} & \multirow{3}{*}{$78 \%$} & \multirow{3}{*}{$100 \%$} & \multirow{3}{*}{ B } & \\
\hline & \begin{tabular}{|l|} 
No. 5 \\
\end{tabular} & 65.2 & & & & & & & & & & & \\
\hline & \begin{tabular}{|l|} 
No. 7 \\
\end{tabular} & 63.6 & & & & & & USD685 & & & & & \\
\hline \multirow{2}{*}{ TypeA } & \begin{tabular}{|l|} 
正加力 \\
\end{tabular} & \multirow{2}{*}{53.9} & \multirow{2}{*}{300} & \multirow{2}{*}{450} & \multirow{2}{*}{450} & \multirow{2}{*}{450} & \begin{tabular}{|l|}
$6-\mathrm{D} 19$ \\
\end{tabular} & \multirow{2}{*}{ USD685 } & \multirow{2}{*}{0.76} & \multirow{2}{*}{$78 \%$} & \multirow{2}{*}{$100 \%$} & C. & 2) \\
\hline & 負加力 & & & & & & \begin{tabular}{|l|}
$4-D 19$ \\
\end{tabular} & & & & & & 2) \\
\hline TypeA & \begin{tabular}{|l|} 
No. 4 \\
\end{tabular} & 53.1 & 280 & 400 & 420 & $420 \mathrm{t}$ & \begin{tabular}{|l|}
$6-\mathrm{D} 19$ \\
\end{tabular} & \begin{tabular}{|l|l} 
SD 90 \\
\end{tabular} & 0.75 & $75 \%$ & $100 \%$ & C & 3) \\
\hline & \begin{tabular}{|l|} 
No. 5 \\
\end{tabular} & 59.2 & & & & & \begin{tabular}{|l|}
$7-D 19$ \\
\end{tabular} & \begin{tabular}{|l} 
USD 685 \\
\end{tabular} & & & & & \\
\hline 無 & \begin{tabular}{|l|} 
No. 1 \\
\end{tabular} & 94.7 & & & & & & & - & $100 \%$ & 0 & $\mathrm{~A}$ & 4) \\
\hline TypeA & \begin{tabular}{|l|} 
No. 2 \\
\end{tabular} & 94.1 & 250 & 400 & 400 & 400 & 8-D19 & SD 490 & 0.85 & $80 \%$ & $100 \%$ & C & 4) \\
\hline & $0.25 \mathrm{D}$ & & & & & & & & & $75 \%$ & & & \\
\hline TypeA & \begin{tabular}{|l|}
$0.5 \mathrm{D}$ \\
\end{tabular} & 21.1 & 300 & 400 & 350 & 350 & $4-\mathrm{D} 22$ & SD490 & 0.75 & $50 \%$ & $100 \%$ & C & 5) \\
\hline & \begin{tabular}{|l|}
$1.0 \mathrm{D}$ \\
\end{tabular} & & & & & & & & & $0 \%$ & & & \\
\hline & No. 1 & 48.4 & & & & & 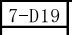 & & & & $43 \%$ & & \\
\hline TypeB & \begin{tabular}{|l|} 
No. 2 \\
\end{tabular} & 40.4 & 325 & 450 & 475 & 475 & 10-D19 & SD490 & 0.80 & $67 \%$ & & $\mathrm{~A}+\mathrm{C}$ & 6) \\
\hline & \begin{tabular}{|l|} 
No. 3 \\
\end{tabular} & 55.9 & & & & & \begin{tabular}{|l|}
$7-\mathrm{D} 19$ \\
\end{tabular} & & & & \begin{tabular}{|l|}
$60 \%$ \\
\end{tabular} & & \\
\hline & \begin{tabular}{|l|} 
No. 1 \\
\end{tabular} & & & 300 & & & & & - & $100 \%$ & & $\mathrm{~A}$ & \\
\hline TypeB & \begin{tabular}{|l|} 
No. 2 \\
\end{tabular} & 33.2 & 250 & 400 & 350 & 350 & $4-\mathrm{D} 22$ & SD490 & 0.75 & $75 \%$ & 0 & 上筋 $\mathrm{A}$ & 7) \\
\hline & \begin{tabular}{|l|} 
No. 3 \\
\end{tabular} & & & 450 & & & & & & $67 \%$ & & 下筋C & \\
\hline
\end{tabular}


(100\%,75\%，67\%)の違いを調べている。ただし，梁上端筋はすべ て通し筋とし，梁下端筋はすべて柱梁接合部に定着している。

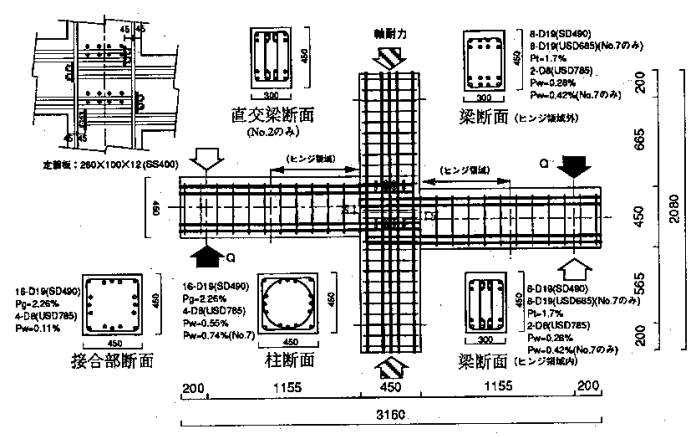

図 7 文献 1)の試験体 (TypeA：貫通定着)

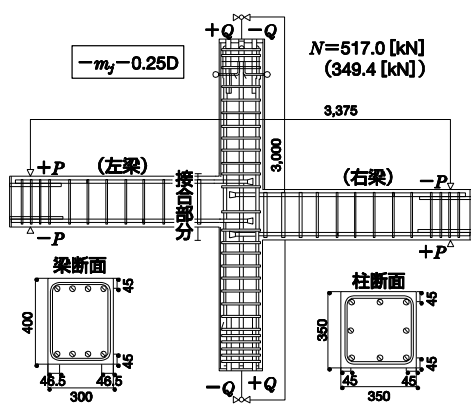

図 8 文献 5)の試験体 (TypeA：非貫通定着)

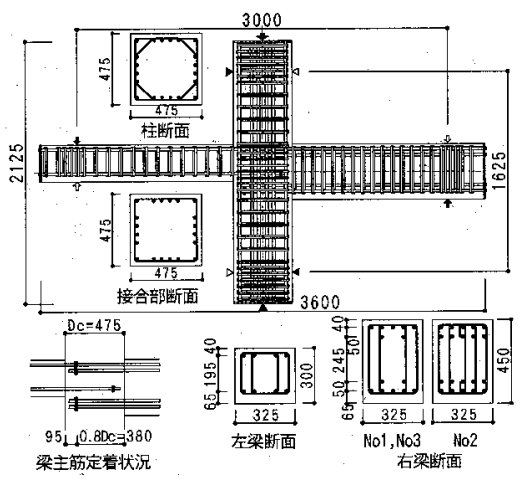

図 9 文献 6) の試験体 (TypeB)

\section{Type A 段差梁付き十字形接合部の検討}

\section{1 実験結果に基づく設計条件}

検討対象試験体の計算耐力および実験值を表 2 に示す。これらを 基に, Type A 段差梁付き十字形接合部の設計条件について検討する。 表 2 中, 梁曲げ終局耐力時柱せん断力 cQgu および接合部せん断耐力 時柱せん断力 Qpu は, 段差なし接合部と同様, 文献 8)の設計式によ って算定した。 $\mathrm{R} 80$ は, 耐力が最大耐力 $\mathrm{Q}_{\max }$ の $80 \%$ に低下した時の限 界層閒変形角実験值であり, 実験結果の破壊形式を併記した。

文献 2)の試験体では, 梁上端筋と下端筋の本数が異なるので, 表 2 に示すように, 梁上端筋が引張側になる正加力および下端筋が引 張側になる負加力について, それぞれ梁曲げ終局耐力時柱せん断力 cQguを算定した。

\section{（1）貫通定着の効果}

文献 1)の実験では, Type A の貫通型定着による段差梁付き試験体 No. 2 の最大耐力実験值 $Q \max$ は段差なし試験体 No. 1 よりも低いが,
限界層間変形角実験值 R80 は段差なし試験体 No. 1 と同程度であり, 梁曲げ降伏後の変形性能が確保される。これは, 試験体 No. 2 での梁 主筋の貫通定着の効果によると考えられる。また, 試験体 No. 1 にお いて $\mathrm{Qmax}_{\max } / \mathrm{cQg}_{\mathrm{gu}}=1.65$ と大きな值になった理由は，同試験体がスラブ 付き $\mathrm{T}$ 形断面梁としていたためであると考えられる。

文献 5) の実験によると, 重なり部内の左右梁主筋がそれぞれ引張 側になる加力時には, 重なり部内の左右梁主筋が定着される接合部 領域でコンクリートのひび割れ幅が顕著に拡大し, 同加力時の最大 耐力実験值は反対側の加力時よりも低下した。ただし, 文献 5) の各 試験体の最大耐力実験值 $\mathrm{Q}_{\max }$ は, $\mathrm{D}_{\mathrm{jh}}=\ell_{\mathrm{ag}}$ として算定した接合部せん 断終局耐力時柱せん断力 Qpu を上回る。

表 2 検討対象試験体の計算耐力および実験值

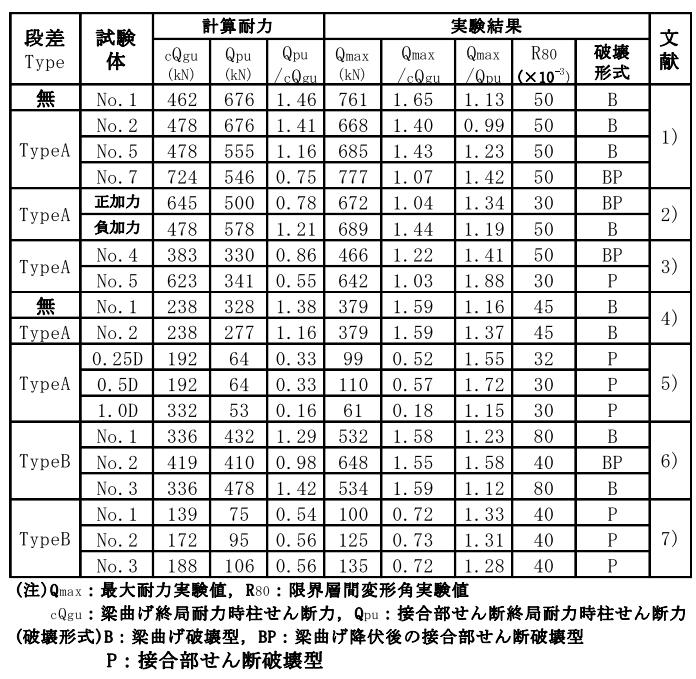

（2）重なり部の効果

Type A 段差梁付き試験体の重なり率は, 表 1 に示すように, 文献 1)の貫通型定着試験体では 78\%, 文献 2) 5) の非貫通型定着試験体 では 0〜80\%である。これらによると，

1）貫通型定着の場合，重なり率が $75 \%$ 以上であれば， $\mathrm{D}_{\mathrm{jh}}=\mathrm{D}_{\mathrm{c}}$ として 接合部せん断終局耐力を算定してもよい。

2）非貫通型定着の場合，重なり 率に係わらず, $\mathrm{D}_{\mathrm{jh}}=\ell \mathrm{ag}$ として 接合部せん断終局耐力を算 定してもよい。ただし, 文献 5)による重なり率 0 の試験体 1. OD の実験によると, 接合部 せん断終局耐力は, 左梁また は右梁がそれぞれ接続する 卜形接合部として算定する 必要がある(図 10 参照)。

(3) 直交梁の効果

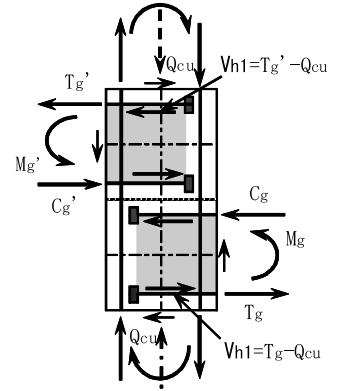

図 10 重なり率 0 段差梁付き 十字形接合部の入力せん断力
段差梁付きの直交梁による接合部被覆率は, 左梁または右梁が接 続する柱梁接合部側面の見付け面積に対する見付け面積内の直交梁 断面積の比率と定義される ${ }^{9}$ 。ここの定義によると, 文献 1)の両側直 交梁付き試験体 No. 1 および No. 2 の接合部被覆率は $300 \mathrm{~mm} \times 350 \mathrm{~mm}$ / $(450 \mathrm{~mm} \times 450 \mathrm{~mm})=52 \%$ である。

表 2 に示すように, 両試験体ともに, 接合部耐力余裕度 Qpu/cQgu が 1 以上の梁曲げ降伏先行型であるが, 最大耐力実験值 $Q \max$ は, 直 
交梁の有無による補正係数 $\phi$ を 1.0 として算定した接合部せん断耐 力時柱せん断力 $\mathrm{Qpu}$ を概ね上回る。

\section{2 終局耐力および変形性能の評価}

Type A 段差梁付き試験体の終局耐力と限界層間変形角 R 80 の検討 結果を図 11 に示す(表 2 参照)。これらによると,

1） Type A 段差梁付き試験体の接合部せん断終局耐力時柱せん断力 Qpu および梁曲げ終局耐力時柱せん断力 cQguは，概ね接合部せん 断余裕度 $\mathrm{Qpu} / \mathrm{cQgu}=1$ を境に, それぞれ最大耐力実験值 $\mathrm{Qmax}$ に対 して安全側に評価される。

2） $\mathrm{Qpu} / \mathrm{cQgu} \geqq 1$ の限界層間変形角実験值 R80 は，梁曲げ降伏型十字 形接合部の目標性能 $\left(40 \times 10^{-3} \mathrm{rad}\right.$. 以上) を満足する。 $40 \times 10^{-3} \mathrm{rad}$. は, 勒性保証型設計指針 ${ }^{9)}$ に示された梁の終局部材角の目安值 (1/50)の 2 倍である。

3） Type A 試験体では, 表 2 に示すように, 接合部せん断余裕度 $\mathrm{Qpu} / \mathrm{cQgu}$ が 0.75 程度以上の場合, 耐力安全率 $\mathrm{Q}_{\max } / \mathrm{Qpu}_{\mathrm{pu}} 1$ 以上 となり，破壊形式は梁曲げ降伏後の接合部破壊となった。

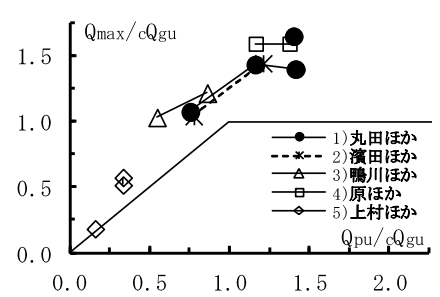

(a) 終局耐力

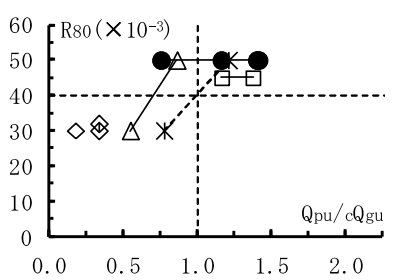

（b）限界層間変形角
図 11 Type A 段差梁付き試験体の検討結果

\section{Type B 段差梁付き十字形接合部の検討}

Type B 段差梁付き試験体の終局耐力と限界層閒変形角の検討結果 を図 12 に示す(表 2 参照)。

文献 6)の試験体では, 梁上端筇の定着筋率が $43 \%$ と $60 \%$ の非貫通定 着であるが，接合部有効せい $D_{j h}$ は柱せい $D_{c}$ と等しいとした。文献 7)の試験体では，梁上端筋はすべて通し筋であり，接合部有効せい D jh は柱せい D c と等しいとした。図 12 によると，

1) Type A 試験体と同様, Type B 段差梁付き試験体の接合部せん断 終局耐力時柱せん断力 Qpu および梁曲げ終局耐力時柱せん断力 cQguは，概ね接合部せん断余裕度 $\mathrm{Qpu} / \mathrm{cQgu}=1$ を境に，それぞれ最 大耐力実験值 $\mathrm{Q}_{\max }$ に対して安全側に評価される。

2） $Q \mathrm{pu} / \mathrm{cQgu} \geqq 1$ の限界層閒変形角実験值 R 80 は, 梁曲げ降伏型十字形 接合部の目標性能 $\left(40 \times 10^{-3} \mathrm{rad}\right.$. 以上) を満足する。

3） TypeB 試験体では，接合部せん断余裕度 Qpu/cQgu が 1 をやや下回 っても, Type A 試験体と同様, 破壊形式は梁曲げ降伏後の接合 部破壞となった。

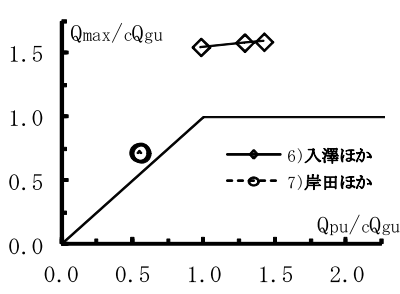

(a) 終局耐力

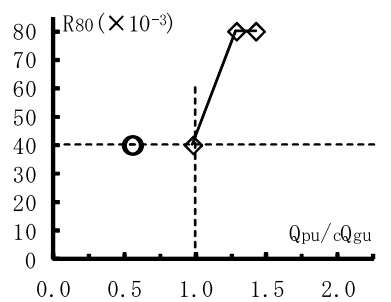

（b）限界層間変形角
図 12 Type B 段差梁付き試験体の検討結果
6. まとめ

本論文では, Type A および Type B の段差梁付き十字形接合部の 設計条件および抵抗機構について考察し, 文献 1）～7）の実験を基に, 段差梁付き十字形接合部のせん断終局耐力に対する (1) 貫通定着の 効果，（2）重なり部の効果，(3) 直交梁の効果について検討した。 これらの検討結果を基に，段差梁付き十字形接合部について，以 下の設計条件を得た。

1） Type A の段差梁付き十字形接合部では, 重なり部梁主筋が貫通 定着の場合, 重なり率が 75\%以上であれば, 左右梁の引張側梁主 筋定着部から材端部圧縮域に向からストラットおよび接合部中 央のストラットの効果より，接合部せん断終局耐力 $V_{\text {puh }}$ は, $\mathrm{D}_{\mathrm{jh}}=\mathrm{D}_{\mathrm{c}}$ として式 (4)で算定してもよい。

2) Type B の段差梁付き十字形接合部では, 重なり部梁主筋が通し 筋または定着筋率 50\%以上の貫通定着の場合, 重なり率が 67\%以 上であれば，接合部せん断終局耐力は， $\mathrm{D}_{\mathrm{jh}}=\mathrm{D}_{\mathrm{c}}$ として式(4)で算 定してもよい。ただし, 重なり部梁主筋が上記の条件を満足し ない場合，重なり率に係わらず，卜形接合部と同様， D jh $=\ell_{\mathrm{ag}}$ と して算定した方がよい。また, 重なり率 0 の場合, 接合部せん 断終局耐力は, 左梁または右梁が接続する 2 つのト形接合部と して算定する。

3）段差梁付き十字形接合部の接合部せん断終局耐力は, 段差なし 接合部と同様, 両側の接合部被覆率が $50 \%$ 以上の場合, $\phi=1$ と して式(4)で算定してもよい。

\section{参考文献}

1） 中村雅彦，別所佐登志，丸田誠：高強度材料を用いた超高層 RC 造柱・はり部分骨組の水平加力実験（その 2. 段差ばり骨組）, 日本建築学会大会梗概集，構造 II , pp. 869-870，1993.9

2）濱田真, 吉松賢二, 石橋久義, 堀江啓 : 梁主筋を機械式定着し た接合部の実験, 日本建築学会大会梗概集, 構造IV, pp. 569-570, 1998. 9

3）鴨川直晶, 今西語龍, 山口芳之, 日高雅樹, 中岡章郎：高強度 材料を用いた超高層鉄筋コンクリート造柱梁接合部に関する実 験的研究 その 2, 日本建築学会大会梗概集, 構造IV, pp. 813-814, 2000.9

4）原孝文ほか 5 名: 高強度材料を用いた $\mathrm{RC}$ 柱梁接合部架構の構造 性能確認実験, 日本建築学会大会梗概集, 構造IV, pp. 247-248, 2001.9

5）廣谷裕貴，上村智彦，石橋一彦，林静雄 : 機械式定着による段 差梁を有する鉄筋コンクリート造梁・柱接合部の抵抗機構, JCI 年次論文集, Vol. 32, No. 2, pp. 319-324, 2010

6）入澤郁雄，林和也，田中清 : 段差梁を有する鉄筋コンクリート 造柱・梁接合部の力学的性状に関する実験的研究, 日本建築学 会大会梗概集，構造IV，pp. 571-572， 1998.9

7）佐藤えり香，佐藤周平，岸田真司：左右の梁せいの異なる鉄筋 コンクリート造柱梁接合部の終局強度に関する実験研究，日本 建築学会大会梗概集, 構造IV, pp. 469-470，2010.9

8）日本建築総合試験所 - 機械式鉄筋定着工法研究委員会 : 機械式 鉄筋定着工法設計指針 (2010 年改定)，2010.5

9）日本建築学会 : 鉄筋コンクリート造建築物の靭性保証型耐震設 計指針・同解説， 1999

[2012 年 10 月 10 日原稿受理 2013 年 1 月 22 日採用決定］ 